\title{
The effects of red soil in removing phosphorus from water column and reducing phosphorus release from sediment in Lake Taihu
}

Lichun Dai and Gang Pan

\begin{abstract}
A natural red soil and a lanthanum-modified soil (LMS) were tested to compare their phosphorus (P) adsorption capacities and their effectiveness in removing $\mathrm{P}$ from the water column and reducing $\mathrm{P}$ release from sediment. The equilibrium of $\mathrm{P}$ adsorption demonstrated that the maximum $\mathrm{P}$ adsorption for the soil was 1.29 and $2.22 \mathrm{mg} \mathrm{g}^{-1}$ at $\mathrm{pH} 8.5$ and 5.5, respectively, and for the LMS these were increased by 45.6 and $77.6 \%$ at $\mathrm{pH} 8.5$ and 5.5, respectively, indicating that the soil was effective in P adsorption and the doping of lanthanum could substantially increase P adsorption. The sediment-water column incubation showed that, due to the $\mathrm{P}$ adsorption of the soil and LMS, the total $\mathrm{P}$ in the water column decreased by $58.5,60.6,68.2$ and $77.2 \%$ for $180 \mathrm{~g} \mathrm{~m}^{-2}$ soil, $900 \mathrm{~g} \mathrm{~m}^{-2}$ soil, $180 \mathrm{~g} \mathrm{~m}^{-2}$ LMS and $900 \mathrm{~g} \mathrm{~m}^{-2}$ LMS treated systems, respectively, in a short time $(6 \mathrm{~h})$, and the capping layer substantially reduced the $P$ release from sediment during column incubation, indicating that the soils were effective in reducing internal P load. However, considering the cost of LMS, the natural soil was suggested to be a cost-effective material to control internal P load.
\end{abstract}

Key words | internal load reduction, lanthanum-modified soil, phosphorus adsorption, phosphorus removal, red soil

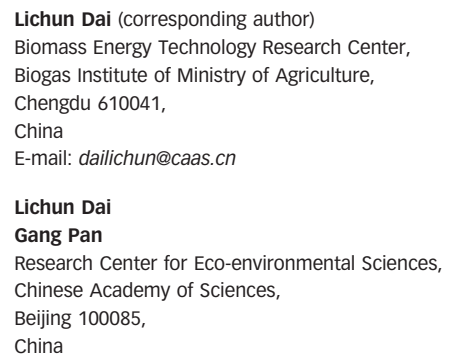

\section{INTRODUCTION}

The mineral resources of $\mathrm{P}$ are becoming limited for agriculture production in many countries (Gilbert 2009), while, ironically, nutrients are accumulating in aquatic environments, causing serious eutrophication around the world (Conley et al. 2009). Eutrophication that drives algal growth in lakes comes directly from the catchment as external $\mathrm{N}$ and $\mathrm{P}$ loads, or recycled from the lake sediments as internal loads from a pool that accumulated during periods of high external loading (Sondergaard et al. 2003). The undesirable algal growth leads to undesirable water turbidity and, often, undesirable biological changes (Paerl \& Huisman 2008). The latter means the loss of biodiversity, including the disappearance of submerged macrophytes, fishes and benthos (Paerl \& Huisman 2008).

Phosphorus availability is the most important factor for the water quality of most lakes (Sondergaard et al. 2003). Only if the nutrient level is reduced to a critical level, can the submerged macrophyte dominated state be achieved (Scheffer et al. 200I); thus the reduction of $\mathrm{P}$ loads is the most effective approach in the remediation of eutrophic doi: $10.2166 /$ wst.2014.022 lakes (Schindler et al. 2008). Phosphorus levels in lakes can be managed through reducing the external and internal loads of lakes. Some lakes have displayed a delay in lake recovery after external loads were controlled (Mehner et al. 2008). One of the reasons is that internal $\mathrm{P}$ loads may be so intense and persistent that they prevent the improvement of water quality for a considerable period after the reduction of external loads (Scharf I999); thus the control of internal $\mathrm{P}$ load is essential to the recovery of eutrophication.

Internal $\mathrm{P}$ load management such as $\mathrm{P}$ inactivation (Hickey \& Gibbs 2009) and capping (Cooke et al. 2005) are applied either as a flocculation agent to sequester $\mathrm{P}$ in the water column or as a capping agent to cover the sediments and block $\mathrm{P}$ release, and have shown great effect in reducing internal $\mathrm{P}$ load in many cases (Cooke et al. 2005). Passive agents (such as sand, gravel and clay (Jacobs \& Forstner 1999)) and active agents (allophane (Yuan \& Wu 2007)), lime (Prepas et al. 200I), aluminium sulphate (Van Hullebusch et al. 2002) and lanthanum-modified clays (Robb et al. 2003; Yuan et al. 2009) are available for the 
reduction of $\mathrm{P}$ efflux from sediment and the $\mathrm{P}$ level in the water column. However, for internal $\mathrm{P}$ load reduction in Lake Taihu, they are not as easily accessible and ecologically safe as the natural red soil from land adjacent to Lake Taihu. Red soils are widely distributed in tropical, subtropical and Mediterranean climatic zones (Volkoff I998), and are characterized by moderate to high amounts of iron and aluminium oxides, including hydroxides and hydrous oxides (Volkoff I998), low P content and high $\mathrm{P}$ retention capacity, and thus may be competitive in eutrophication control. The soil was successfully applied to remove algal blooms (Pan et al. 2006a, b; Zou et al. 2006), to reduce the recruitment of sedimented algae and nutrient release from sediment into overlying water (Pan et al. 20I2a), and to restore submerged macrophytes in the whole of Liaoyangyuan Bay, Lake Taihu (Pan et al. 20II). The in situ effect of the soil as capping agent in reducing $\mathrm{P}$ release from sediment was confirmed in an experiment in Shiba Bay, Lake Taihu (Xu et al. 20I2). However, little is known about its ability in $\mathrm{P}$ adsorption and its short-term effect in removing $\mathrm{P}$ from the water column.

In this study, the main objective is to compare the $\mathrm{P}$ adsorption capacities of the soil and chemically modified soil (lanthanum-modified soil (LMS)) and their effects in removing $\mathrm{P}$ in the water column and controlling internal $\mathrm{P}$ load in Lake Taihu, thus to analyse the cost-effectiveness of the soil in internal P load control in Lake Taihu. The P adsorption capacities of the soil and LMS were measured to estimate their capability in $\mathrm{P}$ removal. The sediment and corresponding overlying water for the column incubation were collected from Meiliang Bay, Lake Taihu, and the sediment was capped by different dosages of soil and LMS, and incubated under controlled conditions to measure the soils' capabilities in removing $\mathrm{P}$ in the water column and preventing $\mathrm{P}$ release from the sediment.

\section{MATERIALS AND METHODS}

\section{Sampling site of sediment and water}

The sampling site $\left(31^{\circ} 31^{\prime} 17.82^{\prime \prime} \mathrm{N}, 120^{\circ} 09^{\prime} 21.84^{\prime \prime} \mathrm{E}\right)$ of sediment and water for column incubation is located in Meiliang Bay, in the northern part of Lake Taihu, China. The water depth at the experimental site is $1.8 \mathrm{~m}$. After reduction of external loads in recent years, internal nutrient load from sediment and degradation of algae cells is a significant driver for the nuisance outbreak of algal blooms (Wang et al. 2007).

\section{Preparation of the $\mathrm{LaCl}_{3}$-modified soils}

The soil used here was collected from land adjacent to Meiliang Bay, Lake Taihu ( $\left.31^{\circ} 28^{\prime} 28.64^{\prime \prime} \mathrm{N}, 120^{\circ} 13^{\prime} 42.68^{\prime \prime} \mathrm{E}\right)$, air dried and sieved through 180 meshes $(74 \mu \mathrm{m})$ before use. The LMS was prepared following the method of Yuan et al. (2009). Ten grams of soil was added into $50 \mathrm{~mL}$ of $2 \%(\mathrm{w} / \mathrm{w})$ $\mathrm{LaCl}_{3}$ solution (initial $\mathrm{pH}$ 8.3). Then the mixture was shaken for $48 \mathrm{~h}$ at $25^{\circ} \mathrm{C}$ and placed into an autoclave at $200 \mathrm{kPa}$ for $1 \mathrm{~h}$. After this, the mixture was filtered through a $0.45 \mu \mathrm{m}$ membrane and the residue was washed with deionized water three times. The residue was placed in the oven at $60^{\circ} \mathrm{C}$ for $12 \mathrm{~h}$, and then dried at $100{ }^{\circ} \mathrm{C}$ and sieved through 180 meshes $(74 \mu \mathrm{m})$. The Fe, Al, Mn, Ca and La in the soil and LMS (Table 1) were measured using inductively coupled plasma atomic emission spectroscopy after fusing soil/LMS $(0.5 \mathrm{~g})$ with $0.2 \mathrm{~g}$ $\mathrm{LiBO}_{2}$, followed by extraction with $4 \% \mathrm{HNO}_{3}$ (Xu et al. 20I2).

\section{Phosphorus adsorption for soil and LMS}

For the equilibrium experiments, $0.2 \mathrm{~g}$ soil or LMS was added into a $50 \mathrm{~mL}$ polyethylene tube with $30 \mathrm{~mL}$ phosphate solution $\left(\mathrm{KH}_{2} \mathrm{PO}_{4}\right.$, analytical grade) in various initial concentrations. The initial $\mathrm{pH}$ of the solution was adjusted to 5.5 $( \pm 0.05)$ and $8.5( \pm 0.05)$ with $0.1 \mathrm{M} \mathrm{HCl}$ and $0.1 \mathrm{M} \mathrm{NaOH}$ solutions. The mixture was shaken at $25^{\circ} \mathrm{C}, 200 \mathrm{rpm}$ for $12 \mathrm{~h}$. After $12 \mathrm{~h}$ of equilibration, the mixture was centrifuged and the $\mathrm{P}$ in the supernatant was measured by the Mo-Sb-Vc colorimetric method (Wei et al. 2002) Each experiment had two replications, and the mean values were used for the calculation of $\mathrm{P}$ adsorption capacity. The equilibrium adsorption capacity was calculated by the equation:

$Q=V\left(C_{0}-C_{e}\right) / m$

where $Q$ is the adsorption capacity $\left(\mathrm{mg} \mathrm{g}^{-1}\right), V$ is the volume of solution $(\mathrm{mL}), C_{0}$ and $C_{e}$ are the initial and equilibrium concentration of phosphate $\left(\mathrm{mg} \mathrm{L}^{-1}\right)$, respectively, and $m$ is the weight of adsorbent (g).

For the adsorption kinetics experiments, the soil and LMS (1 g) were added into two $1,000 \mathrm{~mL}$ flasks with $500 \mathrm{~mL}$ of $50 \mathrm{mg} \mathrm{L}^{-1} \mathrm{KH}_{2} \mathrm{PO}_{4}$. The initial $\mathrm{pH}$ was adjusted

Table 1 | The elemental composition of the soil and LMS

\begin{tabular}{llllll} 
& Al (\%) & Fe (\%) & La (\%) & Ca (\%) & Mn (\%) \\
\hline Soil & 5.88 & 3.26 & $<0.005$ & 0.26 & 0.068 \\
LMS & 5.82 & 3.29 & 0.88 & 0.10 & 0.048 \\
\hline
\end{tabular}


to 8.5 with $0.1 \mathrm{M} \mathrm{HCl}$ and $0.1 \mathrm{M} \mathrm{NaOH}$ solutions. Then the mixture was shaken at $25^{\circ} \mathrm{C}, 200 \mathrm{rpm}$. The suspension (5 mL) was sampled and filtered using $0.45 \mu \mathrm{m}$ membrane at $0.5,1,2,3,4,6,8$ and $12 \mathrm{~h}$, respectively. The rate of $\mathrm{P}$ adsorption was determined from the amount of $\mathrm{P}$ adsorbed at various times.

\section{Column incubation}

The soil and LMS were tested for their effects in removing $\mathrm{P}$ from the water column and reducing internal $P$ load. Fifteen plexiglass columns with an inner diameter of $8.4 \mathrm{~cm}$ and height of $50 \mathrm{~cm}$ were used as incubation columns. The sediment and lake water were sampled from Meiliang Bay, Lake Taihu, in October 2011. The sediment was homogeneously mixed before use. The lake water was filtered using a Waterman GF/C membrane before use. The sediment was added into the column to the height of $10 \mathrm{~cm}$, and then the filtered lake water $(1 \mathrm{~L})$ was added into the column by syphon. Then, the soil or LMS was added to different columns at doses of 180 and $900 \mathrm{~g} \mathrm{~m}^{-2}$. The initial nutrient concentrations in the overlying water of the column are shown in Table 2. Column incubation was conducted in triplicate at $25^{\circ} \mathrm{C}$. Water samples $(40 \mathrm{~mL})$ for all treatments were collected after $6 \mathrm{~h}$, and then on days 2, 7, 14 and 21. Water samples were collected $10 \mathrm{~cm}$ above the sediment-water interface by syringe, then $40 \mathrm{~mL}$ of filtered lake water was

Table 2 | The initial nutrient concentration in the overlying water

\begin{tabular}{llllll} 
Nutrients & $\mathbf{T N}$ & $\mathbf{N O}_{\mathbf{3}} \mathbf{- N}$ & $\mathbf{N H}_{\mathbf{4}}-\mathbf{N}$ & $\mathbf{T P}$ & $\mathbf{S R P}$ \\
\hline Concentration $\left(\mathrm{mg} \mathrm{L}^{-1}\right)$ & 2.47 & 1.63 & 0.69 & 0.15 & 0.07 \\
\hline
\end{tabular}

added to maintain the total overlying water volume. Total$\mathrm{P}$ (TP) was determined using potassium persulfate digestion by the Mo-Sb-Vc colorimetric method (Wei et al. 2002) and soluble reactive phosphate (SRP) by the same method.

\section{Calculation of P flux}

The fluxes were the average fluxes of $\mathrm{P}$ across the watersediment interface, which were calculated by the following equation (Pan et al. 20I2a):

$F_{i}=\left[V\left(c_{n}-c_{0}\right)+\sum_{j-1}^{n} V_{j-1}\left(c_{j-1}-c_{a}\right)\right] /(S \cdot t)$

where $F_{i}$ is the average flux until day $i\left(\mathrm{mg} \mathrm{m}^{-2} \mathrm{~d}^{-1}\right) ; V$ and $V_{j-1}$ are the volume of overlying water (L) and the volume for sampling water (L) on day $j-1$, respectively; $c_{0}, c_{n}$ and $c_{j-1}$ are the phosphorus concentration $\left(\mathrm{mg} \mathrm{L}^{-1}\right)$ before treatment, on day $n$ and day $j-1$, respectively; $c_{a}$ is the phosphorus concentration of the water for compensating sampled water $\left(\mathrm{mg} \mathrm{L}^{-1}\right) ; S$ is the area of the water column $\left(\mathrm{m}^{2}\right) ; t$ is the time for incubation (day). All the fluxes presented here were the accumulated results for 21 days.

\section{RESULTS AND DISCUSSION}

\section{P adsorption characteristics}

The $\mathrm{P}$ adsorption capacity considerably increased with the phosphate equilibrium concentration (Figure 1(a)). The LMS displayed a rapid increase in the adsorption capacity
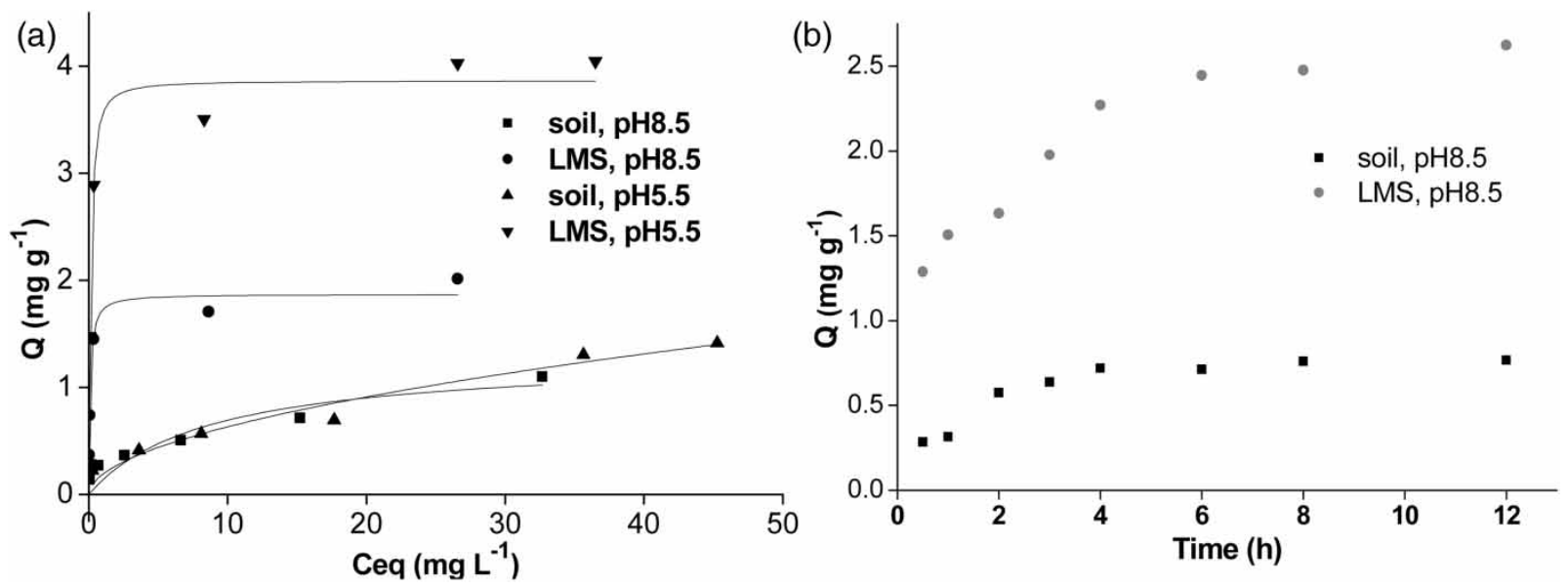

Figure 1 | The P adsorption isotherms (a) and kinetics (b) for the soil and LMS (Q: adsorption capacity; Ceq: equilibrium concentration). 
with an increase in the equilibrium solution concentration, followed by a plateau at equilibrium, demonstrating typical Langmuir isotherm characteristics (Figure 1(a)). However, the soil did not show a rapid increase in adsorption capacity with the increase of equilibrium concentration (Figure 1(a)). At initial $\mathrm{P}$ concentration $40 \mathrm{mg} \mathrm{L}^{-1}$, the adsorption capacity of soil was 1.10 and $1.31 \mathrm{mg} \mathrm{g}^{-1}$ for $\mathrm{pH} 8.5$ and 5.5, respectively, and those of LMS were 2.01 and $4.05 \mathrm{mg} \mathrm{g}^{-1}$ for $\mathrm{pH} 8.5$ and 5.5. These results indicated that the doping of La could improve the capability of the soil for $\mathrm{P}$ adsorption. The soil and LMS exhibited much higher equilibrium adsorption capacities at $\mathrm{pH} 5.5$ than pH 8.5 (Figure 1(a)), indicating that they had better adsorption capacities under acid condition. This is likely attributed to the fact that a higher $\mathrm{pH}$ causes the surface of soil and LMS to carry more negative charges and thus to more significantly repulse the negatively charged species in solution (Wasay et al. I996; Ou et al. 2007), and with the increase of $\mathrm{pH}$, the surface would be negatively charged, which would impair the interactions between phosphate and adsorbents (Wasay et al. I996; Yuan et al. 2009). The kinetics results showed that the adsorption of phosphate for the soil and LMS is attained at about $4 \mathrm{~h}$ (Figure 1(b)). This result was in agreement with the investigation that the P-clay adsorption reaction is rapid, with equilibrium being reached within 4-8 h (Edzwald et al. 1976).

\section{Internal P load reduction}

After $6 \mathrm{~h}$, the TP and SRP in the $180 \mathrm{~g} \mathrm{~m}^{-2}$ soil-treated system were decreased by 58.5 and $68 \%$, respectively, while those in $900 \mathrm{~g} \mathrm{~m}^{-2}$ soil-treated system were decreased by 60.6 and 94.6\%, respectively (Table 3 and Figure 2). The $\mathrm{TP}$ in 180 and $900 \mathrm{~g} \mathrm{~m}^{-2}$ LMS-treated systems was decreased by 68.2 and $77.2 \%$, respectively, and the SRP concentration in LMS-treated systems was reduced to zero (Table 3 and Figure 2). Two days after the treatment, TP and SRP in the soil- and LMS-treated systems still did not show a significant increase $(P>0.05)$ (except for SRP in $180 \mathrm{~g} \mathrm{~m}^{-2}$ soil-treated system) (Figure 2). These results indicated that the soil and LMS had an immediate effect in removing $\mathrm{P}$ from the water column. This effect may be due to the adsorption of $\mathrm{P}$ in the water column by the soil and LMS when they were added into the water column, so the $\mathrm{P}$ in the water column could be removed rapidly.

The TP in the control was gradually increased during column incubation, and the SRP in the control showed a decrease in the first 2 days, which may be a result of the activity of benthos (such as Limnodrilus hoffmeisteri (Wu et al. 20II)) and algae. The burrowing of benthos could increase the TP concentration in the water column ( $\mathrm{Wu}$ et al. 20II), and the growth of algae in the water column could absorb SRP from the water column during the initial

Table 3 The decrease of TP and SRP concentration after $6 \mathrm{~h}$

\begin{tabular}{|c|c|c|c|c|c|}
\hline & Control & $180 \mathrm{~g} \mathrm{~m}^{-2}$ soil & $900 \mathrm{~g} \mathrm{~m}^{-2}$ soil & $180 \mathrm{~g} \mathrm{~m}^{-2}$ LMS & $900 \mathrm{~g} \mathrm{~m}^{-2}$ LMS \\
\hline TP decrease & $37.85 \%$ & $58.47 \%$ & $60.60 \%$ & $68.13 \%$ & $77.20 \%$ \\
\hline SRP decrease & $11.43 \%$ & $68.00 \%$ & $94.57 \%$ & $100.00 \%$ & $100.00 \%$ \\
\hline
\end{tabular}
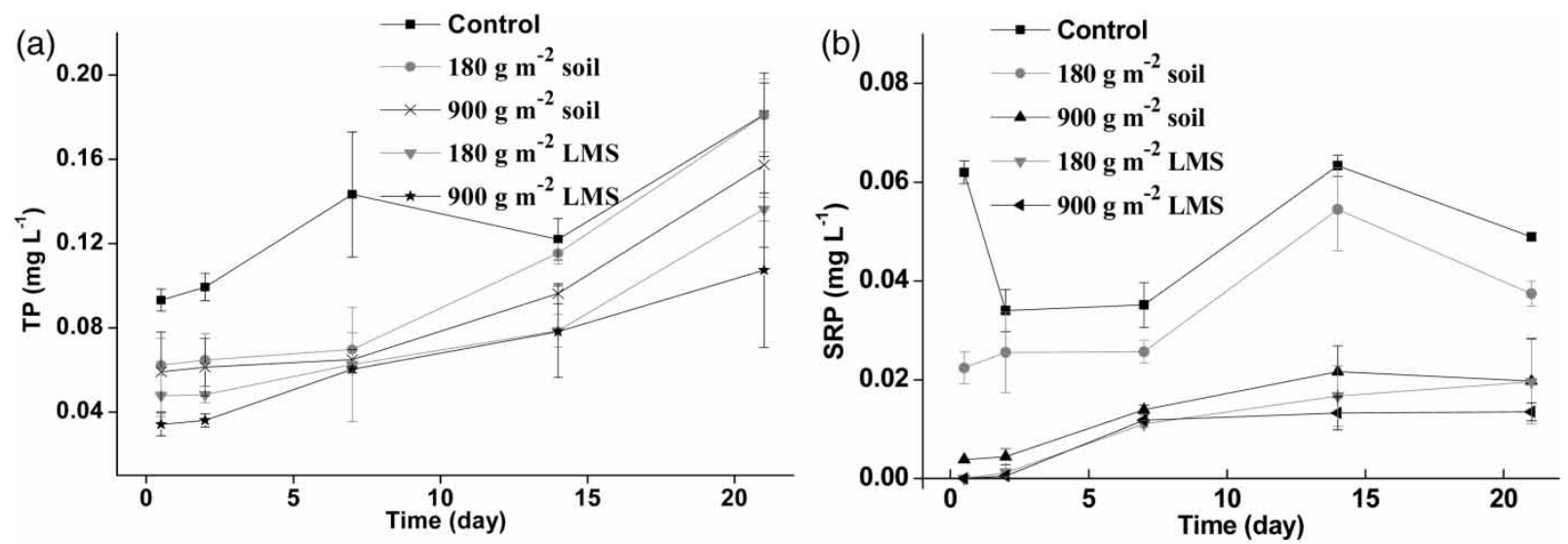

Figure 2 | The TP (a) and SRP (b) changes during column incubation. 
time. The benthos and algae in the sediment of the treated systems could not break through the physical block effect of the capping layer during the initial period, so the TP and SRP could not show the same dynamics as the control during the initial period. Following the initial rapid decrease of TP and SRP in treated systems, the TP and SRP were substantially increased thereafter. The increase of P level in the treated systems may have resulted from the bioturbation from benthos (Galvez-Cloutier et al. 2012) and the decrease of redox potential of the capping layer (Pan et al. 20I2a). However, the soil- and LMS-treated systems still showed lower concentrations than the control during column incubation (Figure 2).

During column incubation, a positive flux of TP from sediment to the overlying water was observed for the control $\left(0.30 \mathrm{mg} \mathrm{m}^{-2} \mathrm{~d}^{-1}\right)$ (Figure 3$)$. However, the average TP flux was entirely reversed into a negative flux in the soil- and LMS-treated systems (Figure 3). The average $\mathrm{PO}_{4}-\mathrm{P}$ flux was $-0.13 \mathrm{mg} \mathrm{m}^{-2} \mathrm{~d}^{-1}$ in the control system (Figure 3). This was reduced in the 180 and $900 \mathrm{~g} \mathrm{~m}^{-2}$ soil treatments, and further reduced for the 180 and $900 \mathrm{~g} \mathrm{~m}^{-2}$ LMS treatments (Figure 3). These results indicated that the soil and LMS could reduce internal P load, and LMS was more effective than the soil in controlling internal $\mathrm{P}$ load. Xu et al. (20I2) found that the soil capping layer on the native sediment had a higher content of active $\mathrm{Al}$ and $\mathrm{Fe}$, and Pan et al. (20I2b) found that the soil capping layer had a much higher dissolved oxygen than the native sediment; so the soil capping layer would reduce the mobility of $\mathrm{P}$ in the native sediment, thus reducing $\mathrm{P}$ release from the sediment into overlying water.

Even though the soil and LMS reduced the P concentration in the water column and the flux of $\mathrm{P}$ from sediment, they did not exhibit their maximum $\mathrm{P}$ adsorption

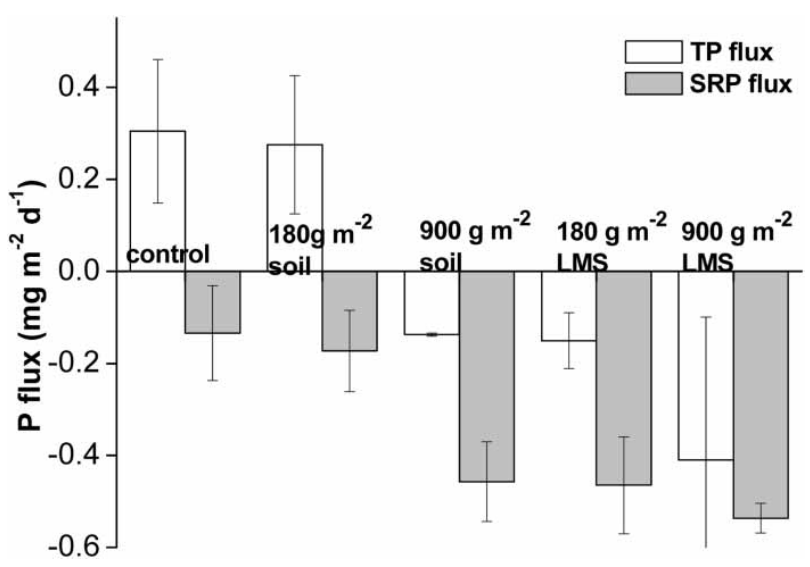

Figure 3 | The average TP and SRP flux during column incubation. capacities. This performance agreed with the results of other P adsorbents, such as Phoslock and allophane (Gibbs et al. 20II). As shown in Figure 1, the P adsorption capacities of adsorbents depend on factors such as $\mathrm{pH}$ and the initial $\mathrm{P}$ concentration, while, in a sedimentwater system, the $\mathrm{pH}$ and $\mathrm{P}$ concentration were different from the conditions when the adsorbents have maximum adsorption capacities. Adsorbents such as Phoslock, with high $\mathrm{P}$ adsorption capacity in low $\mathrm{P}$ concentration, would have great $\mathrm{P}$ removal efficiency in sediment-water systems (Haghseresht et al. 2009; Gibbs et al. 20II). This result suggested that, for practical engineering, the dosage for controlling the internal $\mathrm{P}$ load cannot be calculated by the maximum $\mathrm{P}$ adsorption capacities, but by the capacities under the $\mathrm{P}$ concentration and $\mathrm{pH}$ of lakes. Thus, $\mathrm{P}$ adsorbents which have high $\mathrm{P}$ adsorption capacities at the actual $\mathrm{P}$ concentration in lakes will exhibit high $\mathrm{P}$ removal efficiency in natural lakes. Considering this, $\mathrm{P}$ adsorbents with high adsorption capacities at actual $\mathrm{P}$ concentration should be developed for the internal $\mathrm{P}$ load reduction in natural lakes.

During the last decade, chemical-modified clays which were highly effective in $\mathrm{P}$ adsorption have been applied to manage internal $\mathrm{P}$ load in many aquatic environments (Robb et al. 2003; Reitzel et al. 2005; De Vicente et al. 2008; Egemose et al. 20Io). However, little attention has been paid to the application of natural materials for internal $\mathrm{P}$ load control. The soil cost was about US\$5/ton, while the costs for chemical-modified materials were much higher, e.g. LMS, US\$3,500/ton, and Phoslock, US\$2,500/ton (Pan et al. 20I2a). The results showed that the treatment with a small amount of the soil (180 and $900 \mathrm{~g} \mathrm{~m}^{-2}$ ) could substantially reduce internal $\mathrm{P}$ load (Figures 2 and 3), suggesting that, due to the cost of LMS, the soil was more cost-effective than LMS in internal P load control.

\section{$\overline{\text { CONCLUSIONS }}$}

The red soil from the land adjacent to Lake Taihu and LMS were tested to compare their $\mathrm{P}$ adsorption capacities and their effects in removing $\mathrm{P}$ from the water column and reducing $\mathrm{P}$ release from sediment. The equilibrium of $\mathrm{P}$ adsorption by the soil and LMS demonstrated that the maximum $\mathrm{P}$ adsorptions by the soil were 1.29 and $2.22 \mathrm{mg} \mathrm{g}^{-1}$ at pH 5.5 and 8.5, respectively; those for the LMS were increased by 45.6 and $77.6 \%$ at pH 5.5 and 8.5, respectively, indicating that the soil was effective in $\mathrm{P}$ adsorption, and the modification of the soil by La improved the capacity. The 
sediment-water column incubation showed that, due to the $P$ adsorption of soil and LMS, the TP from the water column was reduced by $58.5,60.6,68.2$ and $77.2 \%$ for $180 \mathrm{~g} \mathrm{~m}^{-2}$ soil, $900 \mathrm{~g} \mathrm{~m}^{-2}$ soil, $180 \mathrm{~g} \mathrm{~m}^{-2}$ LMS and $900 \mathrm{~g} \mathrm{~m}^{-2}$ LMStreated systems, respectively, in a short time $(6 \mathrm{~h})$, and the capping layer of soil and LMS could substantially reduce the P flux from sediment during column incubation, indicating that they were effective in reducing internal $\mathrm{P}$ load. However, considering the cost and effectiveness of LMS, the natural red soil was suggested to be a cost-effective material to remove $\mathrm{P}$ from the water column and reduce internal P load.

\section{ACKNOWLEDGEMENTS}

The study was supported by the Chinese National Basic Research Program (2008CB418105, 2010CB933600) and the Central Public-Interest Scientific Institution Basal Research Fund (0032013002, 2013ZL002).

\section{REFERENCES}

Conley, D. J., Paerl, H. W., Howarth, R. W., Boesch, D. F., Seitzinger, S. P., Havens, K. E., Lancelot, C. \& Likens, G. E. 2009 Controlling eutrophication: nitrogen and phosphorus. Science 323 (5917), 1014-1015.

Cooke, G. D., Welch, E. B., Peterson, S. \& Nichols, S. A. 2005 Restoration and Management of Lakes and Reservoirs. CRC Press, Boca Raton, FL, USA.

De Vicente, I., Huang, P., Andersen, F. Ø. \& Jensen, H. S. 2008 Phosphate adsorption by fresh and aged aluminum hydroxide. Consequences for lake restoration. Environ. Sci. Technol. 42 (17), 6650-6655.

Edzwald, J. K., Toensing, D. C. \& Leung, M. C. Y. 1976 Phosphate adsorption reactions with clay-minerals. Environ. Sci. Technol. 10 (5), 485-490.

Egemose, S., Reitzel, K., Andersen, F. Ø. \& Flindt, M. R. 2010 Chemical lake restoration products: sediment stability and phosphorus dynamics. Environ. Sci. Technol. 44 (3), 985-991.

Galvez-Cloutier, R., Saminathan, S. K. M., Boillot, C., TriffautBouchet, G., Bourget, A. \& Soumis-Dugas, G. 2012 An evaluation of several in-lake restoration techniques to improve the water quality problem (eutrophication) of Saint-Augustin Lake, Quebec, Canada. Environ. Manage. 49 (5), 1037-1053.

Gibbs, M. M., Hickey, C. W. \& Ozkundakci, D. 20II Sustainability assessment and comparison of efficacy of four P-inactivation agents for managing internal phosphorus loads in lakes: sediment incubations. Hydrobiologia 658 (1), 253-275.

Gilbert, N. 2009 The disappearing nutrient. Nature 461 (7265), $716-718$.
Haghseresht, F., Wang, S. \& Do, D. D. 2009 A novel lanthanummodified bentonite, Phoslock, for phosphate removal from wastewaters. Appl. Clay Sci. 46 (4), 369-375.

Hickey, C. W. \& Gibbs, M. M. 2009 Lake sediment phosphorus release management - decision support and risk assessment framework. New Zeal. J. Mar. Fresh. Res. 43 (3), 819-854.

Jacobs, P. H. \& Forstner, U. 1999 Concept of subaqueous capping of contaminated sediments with active barrier systems (ABS) using natural and modified zeolites. Water Res. 33 (9), 2083-2087.

Mehner, T., Diekmann, M., Gonsiorczyk, T., Kasprzak, P., Koschel, R., Krienitz, L., Rumpf, M., Schulz, M. \& Wauer, G. 2008 Rapid recovery from eutrophication of a stratified lake by disruption of internal nutrient load. Ecosystems 11 (7), 1142-1156.

Ou, E., Zhou, J., Mao, S., Wang, J., Xia, F. \& Min, L. 2007 Highly efficient removal of phosphate by lanthanum-doped mesoporous $\mathrm{SiO}_{2}$. Colloid. Surf. A 308 (1-3), 47-53.

Paerl, H. W. \& Huisman, J. 2008 Blooms like it hot. Science 320 (5872), 57-58.

Pan, G., Zhang, M. M., Chen, H., Zou, H. \& Yan, H. 2006a Removal of cyanobacterial blooms in Taihu Lake using local soils. I. Equilibrium and kinetic screening on the flocculation of Microcystis aeruginosa using commercially available clays and minerals. Environ. Pollut. 141 (2), 195-200.

Pan, G., Zou, H., Chen, H. \& Yuan, X. Z. 2006b Removal of harmful cyanobacterial blooms in Taihu Lake using local soils. III. Factors affecting the removal efficiency and an in situ field experiment using chitosan-modified local soils. Environ. Pollut. 141 (2), 206-212.

Pan, G., Yang, B., Wang, D., Chen, H., Tian, B. H., Zhang, M. L., Yuan, X. Z. \& Chen, J. A. 20II In-lake algal bloom removal and submerged vegetation restoration using modified local soils. Ecol. Eng. 37 (2), 302-308.

Pan, G., Dai, L., Li, L., He, L., Bi, L., Li, H. \& Gulati, R. D. 2012a Reducing the recruitment of sedimented algae and nutrient release into the overlying water using modified soil/sand flocculation-capping in eutrophic lakes. Environ. Sci. Technol. 46 (9), 5077-5084.

Pan, G., Dai, L., Li, L., Shang, Y., Li, H., Bi, L., He, L., Wang, L., Wang, D., Li, Q., Li, L., Gu, X., Zhong, J., Yu, Y. \& Yan, Q. 20I2b Eutrophication control using modified local soil/sand induced ecological restoration technology: I. Effect and mechanism on short and long term improvement of water quality. J. Lake Sci. 24 (6), 801-810.

Prepas, E. E., Pinel-Alloul, B., Chambers, P. A., Murphy, T. P., Reedyk, S., Sandland, G. \& Serediak, M. 20oI Lime treatment and its effects on the chemistry and biota of hardwater eutrophic lakes. Freshwater Biol. 46 (8), 1049-1060.

Reitzel, K., Hansen, J., Andersen, F. Ø., Hansen, K. S. \& Jensen, H. S. 2005 Lake restoration by dosing aluminum relative to mobile phosphorus in the sediment. Environ. Sci. Technol. 39 (11), 4134-4140.

Robb, M., Greenop, B., Goss, Z., Douglas, G. \& Adeney, J. 2003 Application of Phoslock ${ }^{\mathrm{TM}}$, an innovative phosphorus binding clay, to two Western Australian waterways: preliminary findings. Hydrobiologia 294 (1-3), 237-243. 
Scharf, W. 1999 Restoration of the highly eutrophic Lingese reservoir. Hydrobiologia 416, 85-96.

Scheffer, M., Carpenter, S., Foley, J. A., Folke, C. \& Walker, B. 200 I Catastrophic shifts in ecosystems. Nature 413 (6856), 591-596.

Schindler, D. W., Hecky, R. E., Findlay, D. L., Stainton, M. P., Parker, B. R., Paterson, M. J., Beaty, K. G., Lyng, M. \& Kasian, S. E. M. 2008 Eutrophication of lakes cannot be controlled by reducing nitrogen input: Results of a 37-year whole-ecosystem experiment. Proc. Natl Acad. Sci. USA 105 (32), 11254-11258.

Sondergaard, M., Jensen, J. P. \& Jeppesen, E. 2003 Role of sediment and internal loading of phosphorus in shallow lakes. Hydrobiologia 506 (1-3), 135-145.

Van Hullebusch, E., Deluchat, V., Chazal, P. M. \& Baudu, M. 2002 Environmental impact of two successive chemical treatments in a small shallow eutrophied lake: Part I. Case of aluminium sulphate. Environ. Pollut. 120 (3), 617-626.

Volkoff, B. 1998 Red and lateritic soils: World scenario. In: Managing Red and Lateritic Soils for Sustainable Agriculture, vol. 1 (J. Sehagal, W. E. H. Blum \& K. S. Gajbhiya, eds). Oxford and IBH Publishing Co., New Delhi, India, pp. 57-74.

Wang, H. J., Lu, J. W., Wang, W. D., Huang, P. S. \& Yin, C. Q. 2007 Spatio-temporal distribution of nitrogen in the undulating littoral zone of Lake Taihu, China. Hydrobiologia 581, 97-108.
Wasay, S., Haran, M. \& Tokunaga, S. I996 Adsorption of fluoride, phosphate, and arsenate ions on lanthanum-impregnated silica gel. Water Environ. Res. 68 (3), 295-300.

Wei, F., Qi, W., Sun, Z., Huang, Y. \& Shen, Y. 2002 Water and Wastewater Monitoring and Analysis Method. China Environmental Science Press, Beijing.

Wu, S., Yan, F., Sun, Y. \& Tan, W. 20II Influence of Limnodrilus hoffmeisteri bioturbation on phosphorus release from sediment. Chinese J. Environ. Eng. 5 (5), 1071-1076.

Xu, D., Ding, S., Sun, Q., Zhong, J., Wu, W. \& Jia, F. 2012 Evaluation of in situ capping with clean soils to control phosphate release from sediments. Sci. Total Environ. 438, 334-341.

Yuan, G. \& Wu, L. 2007 Allophane nanoclay for the removal of phosphorus in water and wastewater. Sci. Technol. Adv. Mater. 8 (1-2), 60-62.

Yuan, X. Z., Pan, G., Chen, H. \& Tian, B. H. 2009 Phosphorus fixation in lake sediments using $\mathrm{LaCl}_{3}$-modified clays. Ecol. Eng. 35 (11), 1599-1602.

Zou, H., Pan, G., Chen, H. \& Yuan, X. Z. 2006 Removal of cyanobacterial blooms in Taihu Lake using local soils. II. Effective removal of Microcystis aeruginosa using local soils and sediments modified by chitosan. Environ. Pollut. 141 (2), 201-205. 